\title{
Egypt etter Hosni Mubarak
}

Hosni Mubarak har styrt Egypt siden I98I. Ikke siden Muhammed ' Ali hersket i landet på begynnelsen av I80o-tallet har Egypt opplevd et så stabilt styre. Men Mubarak er 76 år, og et presidentskifte vil komme innen få år. Hvem etterfølger Hosni Mubarak som egyptisk president? Og hvilke følger vil et presidentskifte ha for landets innenriks- og utenrikspolitikk?

Av Stig Stenslie og Lars Haugom, statsvitere med spesialisering innen Midtøsten og Nord-Afrika.

I NOVEMBER 2003 FIKK Egypts 76-årige president Hosni Mubarak et illebefinnende da han holdt en direktesendt fjernsynstale i parlamentet. Talen måtte avbrytes i 50 minutter. Den offisielle begrunnelsen var at presidenten hadde influensa. Etter dette har imidlertid spekulasjonene om Mubaraks helse og hvem som skal etterfølge ham som president vært førstesideoppslag i Kairos aviser. ${ }^{\mathrm{I}}$ Etterfølgerspørsmålet er sensitivt for egyptiske myndigheter, og har i mange år vært tabu. Saad Eddin Ibrahim, egyptisk sosiolog og demokratiaktivist, ble i 20oI dømt til sju år i fengsel. Den offisielle begrunnelsen for arrestasjonen var at hans forskningsinstitutt, Ibn Khaldun-senteret, hadde mottatt penger fra utenlandske kilder med det formål å undergrave den egyptiske stats inter- esser. En mer troverdig forklaring er at Ibrahim ble straffet for å ha brutt det nevnte tabuet ved å peke på dynastiske tendenser ved arabiske republikker. Den kjente forskeren hadde satt fokus på fremveksten av "monarkiske republikker" i den arabiske verden. Han hevdet at en ny type stat var i ferd med å vokse frem i regionen, jumlukiya, en kombinasjon av republikk (jumhuriya) og monarki (malikiya). ${ }^{2}$ Dette var republikker med monarkiske trekk. Ett av disse trekkene var at presidentens sønn arvet embetet etter sin far. Dette var tilfelle i Syrias hvor Hafez al-Asads sønn, Bashar, etterfulgte sin far som president i 2000. I Egypt heter det på folkemunne at Hosni Mubaraks sønn Gamal er tiltenkt rollen som landets neste president, og at også Egypt skal degenerere til en I08 
monarkisk republikk. Presidenten selv har avvist ryktet. Men få tror på Mubarak.

Tilgangen til relevant og troverdig informasjon om lederskapet i arabiske stater er meget begrenset. Lederskapet legger lokk på beslutningsprosesser, eventuelle konflikter mellom ledende regimepersoner, budsjetter og så videre. Samtidig er ikkeeliten i landet svært opptatt av eliten. Ryktene om hvem som skal overta etter Mubarak som Egypts president florerer i Kairos kafeer. Mye av det empiriske materialet som presenteres i artikkelen bygger på intervjuer forfatterne hadde med akademikere i Egypt våren 2004.

\section{Lederskifte og reform}

En vanlig oppfatning av den arabiske verden er at den politisk sett er meget ustabil. Dette er ikke tilfelle. Tvert imot har regionen siden I970-tallet vært meget stabil. Et møte mellom arabiske ledere i dag ville inkludert mange av de samme menn som hadde makten på I970-tallet, deriblant Libyas Mu' ammar al-Gadafi, Omans sultan Qaboos, Emiratenes sjeik Zayid alNuhayyan, palestinernes leder Yasser Arafat, Jemens president Ali Abdallah Salih og Kuwaits emir Jabir al-Ahmad al-Jabir alSabah. Ørige arabiske land har erfart tilsvarende politiske stabilitet (se vedlegg). Siden r970-tallet har arabiske herskere konger og presidenter - i gjennomsnitt sittet med makten i 20 år.

På slutten av I990-tallet har nye, unge ledere kommet til makten i Syria, Jordan, Marokko og Bahrain. Andre land - deriblant Egypt - vil snart følge etter. Dette har satt i gang en debatt om hvorvidt lederskifter også vil medføre politisk reform i den arabiske verden. ${ }^{3}$

Grunnen til fokuset på lederskifte og politisk reform er en oppfatning blant vestlige forskere om at politikk i arabiske stater i stor grad er et resultat av lederskapets personlige preferanser og egenskaper. For det første hevdes det at det $i$ arabisk-islamske samfunn har vært en tett kobling mellom stat og elite. Ibn Khaldun påpekte allerede på I300-tallet at konseptet om staten i den arabiske verden er knyttet til sirkulasjon og endring, ikke stabilitet og kontinuitet. ${ }^{4}$ Ulike stater og epoker knyttes til navnene på familiedynastier (umayyadene, abbasidene, fatimidene). Også i dag er dette et trekk ved den arabiske verden. Saudi-Arabia er for eksempel det eneste landet $i$ verden som bærer sin styrende families navn. For det andre blir det hevdet at politiske prosesser $i$ arabiske samfunn i betydelig grad formes av trekk ved eliten. Grunnen til dette er at det finnes få historisk nedfelte regler for politiske prosesser. De fleste regimer praktiserer i en eller annen form shura (rådslagning) og ijma' (konsensus), to politiske prinsipper nedfelt i arabisk-islamsk tradisjon. Men arabiske staters konstitusjoner er fattige hva prinsipper for representativt demokrati angår. For det tredje mener en at sosiale klasser eller grupper i liten grad er grunnlag for politisk mobilisering og handling i den arabiske verden. Forskere, som har lagt erfaringer fra vestlige samfunn til grunn, har lett forgjeves etter både en arbeiderklasse og et liberalt borgerskap som potensielle drivkrefter for henholdsvis sosialistisk og kapitalistisk-demokratisk reform i arabiske samfunn.

Spørsmålet om lederskifte i Egypt er interessant av flere grunner. Landet kan sies å utgjøre det geografiske, demografiske, kulturelle og politiske tyngdepunktet i den arabiske verden. Egypt er 
også, ved siden av Saudi-Arabia, USAs viktigste allierte blant de arabiske statene. Dagens regime spiller dessuten en aktiv rolle i forhold til å få gjenopptatt den havarerte fredsprossen mellom Israel og palestinerne. Gjennom de veletablerte forbindelsene Egypt har til både USA, Israel og palestinerne kan landet spille en konstruktiv brobyggerrolle som ingen annen arabisk stat per i dag er i stand til å fylle. Dersom et lederskifte i Egypt skulle medføre en radikal omlegging av landets politikk, vil dette få ringvirkninger i hele regionen. Særlig gjelder dette spørsmålene om økonomisk og politisk liberalisering, og den arabiske verdens forhold til USA og Israel.

\section{Hva sier konstitusjonen?}

Hva sier Egypts konstitusjon om prosedyrene for presidentskifte? Det finnes $\mathrm{i}$ dag ingen klar prosedyre for hvordan Hosni Mubaraks etterfølger skal utpekes. Artikkel 82 i konstitusjonen slår fast at når presidenten ikke er i stand til å utføre sine plikter skal hans utøvende makt gå til visepresidenten. ${ }^{5}$ Både Anwar al-Sadat og Mubarak var velkjente da de ble presidenter etter å ha fungert som visepresidenter $\mathrm{i}$ en årrekke. Men Mubarak har aldri utpekt en visepresident siden han etterfulgte Sadat i I98I. De ganger han har blitt konfrontert med dette har han vist til artikkel 84 som spesifiserer at lederen for parlamentet eller i neste omgang lederen for Høyesterett, i fravær av en visepresident, skal fungere som president inntil parlamentet velger en kandidat. Dette må skje innen 60 dager. Kandidaten vil så bli presentert parlamentet for ratifisering.

I realiteten forventes det at en håndfull generaler - og ikke parlamentet - vil utpeke kandidaten. Etablert praksis i Egypt er at presidentene som innsatt etter I952 - Nasser, Sadat og Mubarak - har bakgrunn fra de væpnede styrkene, regimets viktigste bærebjelke. En folkeavstemning vil gi den nye presidenten et skinn av å være

\section{m \\ Mubarak har aldri utpekt en visepresident siden han etterfulgte Sadat $i 1981$.}

valgt av folket, men det er liten grunn til å tro at resultatet av en slik avstemning vil være mindre manipulert enn andre politiske valg i Egypt.

\section{Tre kandidater}

Blant spekulasjonene om Hosni Mubaraks mest sannsynlige etterfølger, er det særlig tre navn som går igjen: General Mohamed Hussein at-Tantawi, general Omar Suleyman og Gamal Mubarak. ${ }^{6}$

General Tantawi: Egypts forsvarsminister, general Tantawi, nevnes som en mulig neste president i landet. Den 69-årige generalen er veteran fra krigene mot Israel i I956, I967 og I973. Han er en av Mubaraks mest lojale støttespillere, og har en rekke ganger representert presidenten i offisielle sammenhenger. Tantawi er også blant de regjeringsmedlemmene som beholdt sin post etter regjeringsskiftet i juli i år. Forsvarsministeren skal imidlertid ha alvorlige helseproblemer, og betraktes derfor som en mindre sannsynlig kandidat til presidentembetet. Han skal i dag heller ikke ha særlig stor støtte blant offiserene i de væpnede styrker.

General Suleyman: I motsetning til i 
Syria og de palestinske selvstyreområder, hvor det finnes flere rivaliserende etterretnings- og sikkerhetsledere med til dels overlappende ansvarsområder, er det i Egypt en ubestridt leder innenfor dette feltet: Omar Suleyman. Sjefen for den egyptiske etterretningstjenesten gjennom ti år, general Suleyman, blir av mange betraktet som den nest mektigste mannen i det egyptiske regimet. Lite er offentlig kjent om Egypts etterretningssjef. Han er en mann som særlig innad i landet opererer i kulissene, og mange egyptere har trolig aldri hørt hans navn. General Suleyman, som nå er rundt 60 år, blir beskrevet som en tøff leder og en lojal støttespiller for Hosni Mubarak. I løpet av Suleymans periode som etterretningssjef har blant annet landets radikale islamistbevegelse blitt knust. Suleyman har siden april 2002 fungert som mellommann i forhandlingene mellom Israel og palestinerne. Til tross for at forhandlingene så langt ikke har ført frem, betraktes Suleyman som en utenrikspolitisk tungvekter, og en langt viktigere aktør i fredsforhandlingene enn Egypts utenriksminister. Innad i Egypt betraktes han i økende grad som en seriøs kandidat til å etterfølge Hosni Mubarak i presidentembetet.

General Suleymans svakhet, i motsetning til Tantawi, er at han er lite kjent blant egyptere flest. Både Sadat og Mubarak var velkjente da de ble presidenter etter å ha fungert som visepresidenter i en årrekke. For de egypterne som kjenner til Suleyman er han en fryktet snarere enn en populær person. Suleyman kan imidlertid også tenkes som en overgangsfigur i presidentembetet dersom Mubarak plutselig skulle falle fra, og dersom sikkerhetssituasjon på det tidspunktet blir vurdert til å være

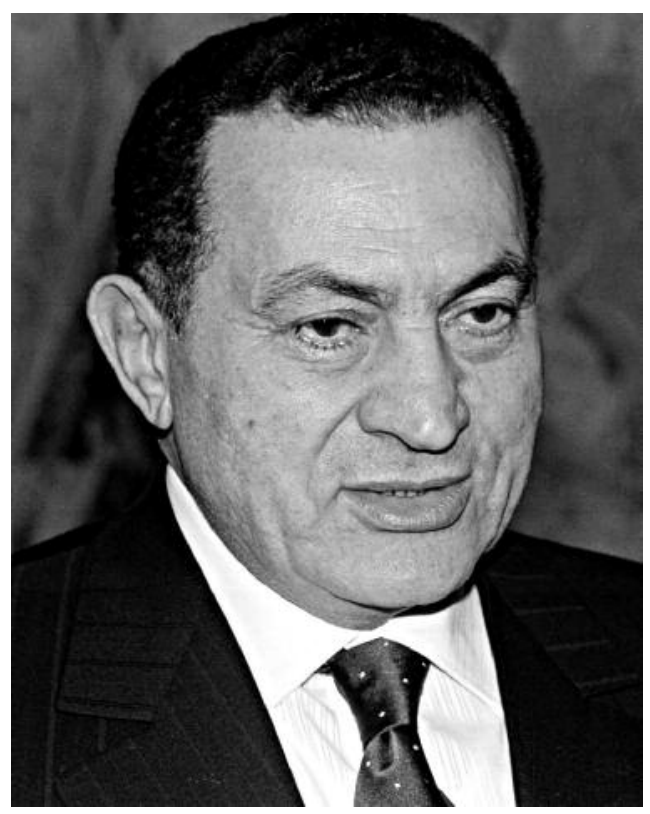

prekær. Et vellykket attentatforsøk mot Mubarak ville være en slik situasjon.

Både Tantawi og Suleyman begynner å dra på årene. Samtidig er Mubaraks helse tilsynelatende utmerket. Dette kan bety at listen over kandidater endres radikalt de neste årene. Men det er en allmenn oppfatning at Egypts neste president - som Nasser, Sadat og Mubarak - vil ha bakgrunn fra militærapparatet.

Under visse omstendigheter er det likevel mulig at den etablerte praksis brytes, og at Egypt vil følge Syrias eksempel hvor Hafez al-Asads sønn, Bashar, etterfulgte sin far som president i 2000 . Mange egyptere snakker derfor i dag om Gamal Mubarak som en fremtidig president.

Gamal Mubarak: Den sterkeste arabiske kritikken av valget av Bashar til president kom fra Egypt. Til tross for dette; det er en rekke indikasjoner på at Hosni Mubarak ønsker at hans sønn skal bli landets neste president. Gamal er ennå ung. Hans alder er ukjent, men han er trolig rundt 40 år. Han har ikke militær bakgrunn. Gamal er 
utdannet ved American University in Cairo (AUC) og jobbet deretter i flere år som foretningsmann i London. Gamal returnerte til Kairo i I996, og har siden da hatt en rekke politiske verv i National Democratic Party (NDP), Egypts statsbærende parti. I 2002 grunnla han Future Generation Foundation (FGF), en ikke-statlig organisasjon med den målsetting å forberede unge egyptere for arbeidsmarkedet. Per i dag leder Gamal NDP' s Policies Secretariat, et organ med ansvar for å utforme partiets politikk. Sekretariatet har blitt et samlingssted for de yngre kreftene i NDP som presser på for reformer i partiet. Utnevnelsen av Gamal som leder for dette sekretariatet har satt fart i spekulasjonene om at han er tiltenkt rollen som Egypts fremtidige president. Gamal kan av faren ha blitt satt til å lede sekretariatet for å få politisk erfaring, samt å bygge opp et image som en reformvillig politiker.

Til tross for sin nyvunne posisjon innen partiet er Gamal på ingen måte noen selvskreven presidentkandidat. Han nyter knapt noen stor folkelig popularitet, og rykter vil ha det til at han er korrupt. På folkemunne går han under navnet "Mr Twenty Percent.” Dertil kommer Gamals manglende militære bakgrunn som vil gjøre det vanskelig for ham å finne støtte hos landets mektige forsvarsledelse.

Hosni Mubarak har en rekke ganger avvist spekulasjonene om at han ønsket sønnen som en president. I 2000 uttalte han følgende: “We are not a monarchy. We are the Republic of Egypt, so refrain from comparing us to other countries in this region." 7 Senest i januar 2004 uttalte han på egyptisk radio: "We are a republican regime and there is no regime inheritance in Egypt." ${ }^{8}$ For å underbygge dette har han gitt Gamal en lavere offisiell profil i Egypt. Mubarak har heller ikke tatt skritt i retning av å presse gjennom en konstitusjonell reform som kan åpne presidentembetet for sønnen. På den annen side er det liten tvil om at Gamal er tiltenkt og forberedes for en rolle i det egyptiske regimet i fremtiden. Om denne rollen faktisk er presidentembetet er imidlertid en godt bevoktet hemmelighet som trolig bare presidenten selv og eventuelt noen få av hans betrodde medarbeidere kjenner svaret på.

\section{Fra far til sønn?}

Hvor sannsynlig er det at Gamal vil etterfølge sin far som Egypts president? Dersom en antar at det foreligger planer om en dynastisk maktoverføring er det to forhold som vil være bestemmende for om dette vil lykkes: hvor snart Mubarak faller fra og sikkerhetssituasjonen i landet.

Mubaraks bortgang: Dersom Mubarak dør snarlig og uventet er det sannsynlig at en fremstående og sterk militærleder vil bli utpekt til president for å sikre landets stabilitet. Helsen til Egypts sterke mann er en statshemmelighet. Men per i dag virker han frisk. Mubarak holder taler og reiser på statsbesøk til utlandet. Han pleier sin helse gjennom en årlig ferietur til Sinai, og tilbringer somrene på et feriested utenfor Alexandria for å slippe unna heten i Kairo. Men når Mubarak dør er selvfølgelig umulig å forutsi. Gamal har per i dag en for svak posisjon både innenfor NDP og regimet for øvrig til å kunne ta farens plass. Tantawi og Suleyman vil derfor være mer sannsynlige kandidater. Dersom Mubarak på den annen side lever og kan fungere som president i ytterligere fem til ti år vil han trolig ha tid nok til å bygge opp tilstrekkelig støtte om sønnens kandidatur 
samt å eliminere eventuell motstand.

Mubarak er i ferd med å bygge opp en maktbase for sønnen. I tillegg til posisjonen innad i NDP skal Gamal ha fått en viktig rolle i presidentpalasset. De som søker en mellommann (wasit) de kan bruke for å nå frem til presidenten kan angivelig velge mellom to-tre nøkkelrådgivere, hans kone eller sønn. I økende grad, spesielt i økonomiske spørsmål, går folk angivelig til

\section{mom}

Det er en rekke indikasjoner på at Hosni Mubarak ønsker at hans sønn skal bli landets neste president.

Gamal. Mange mener det er presidentens kone Suzanne, snarere enn Hosni Mubarak selv, som er den reelle pådriveren for å fremme sønnens presidentkandidatur. Videre hevdes det at Mubarak søker å fremme sønnens presidentkandidatur i Washington. Gamal har ledet egyptiske delegasjoner til USA for å drøfte menneskerettigheter og Palestina-konflikten de to forhold som har skapt mest spenning mellom Egypt og USA. ${ }^{9}$

Mubarak har tidligere vist vilje og evne til å rydde potensielle rivaler av veien. To sterke menn ble tidligere nevnt som hans mulige etterfølgere: Abd al-Halim Abu Ghazzala, forsvarsminister og presidentrådgiver fra I983 til I993 og Amr Musa, utenriksminister fra I99I til 200I, nå generalsekretær i Den arabiske liga. Ingen av disse er imidlertid lenger aktuelle som Mubaraks etterfølger. Ghazzalis politiske karriere var knyttet opp til den militære konflikten med Israel. Han avsluttet sin periode som forsvarsminister da Taba ble levert tilbake i i989, og fortsatte som presidentrådgiver til Osloavtalen ble undertegnet i I993. For diplomaten Amr Musa ble arbeidet som utenriksminister nært forbundet med nettopp Osloprosessen, og hans overføring til generalsekretærstillingen falt sammen med sammenbruddet i fredsprosessen i 200I. Det er svært trolig at Amr Musa ble overført til Den arabiske liga fordi presidenten mente at han var i ferd med å bli for populær blant egypterne. ${ }^{\text {Io }}$

Sikkerhetssituasjonen: Dersom det er betydelig uro innad i Egypt, for eksempel som en følge av en konfrontasjon mellom regimet og radikale elementer av islamistbevegelsen, eller regionalt, forårsaket av et mer spent forhold til Israel, vil det igjen være mest sannsynlig at en fremstående og sterk militærleder vil bli utpekt til president.

På den andre siden, dersom sikkerhetssituasjonen er stabil, vil dette styrke kandidaturet til en president med en sivil agenda. Gamal har gjennom sine roller i NDP bygget opp en krets av støttespiller bestående av unge teknokrater og foretningsmenn som ønsker økonomisk og politisk reform. Gamal kan for mange av disse egypterne fremstå som det best mulige alternativet til dagens tilårskommende lederskap. Med sitt moderne image og sivile bakgrunn vil han trolig appellere til de som ønsker en reformorientert og fremtidsrettet leder, og dersom alternativet er en person fra de militæres rekker vil mange foretrekke Gamal.

\section{Hva med grasrota?}

Hva med egypterne? Hvordan vil de forholde seg til en dynastisk maktovertakelse? Egypt har i dag en befolkning som i stor grad er politisk desillusjonert og som 
ser små muligheter til et reelt regimeskifte i overskuelig fremtid. Egypterne på gata vil trolig tenke at et lederskifte ikke vil spille noen rolle. Uansett hvem den nye lederen blir, Gamal eller noen annen, vil han bli betraktet som en videreføring av det nåværende regimet.

Til tross for egypternes passivititet, vil likevel regimet selv kunne engasjere folket i etterfølgerspørsmålet. Dette vil kunne skje gjennom Egypts forbudte islamistparti, Muslimbrødrene, som har bred oppslutning på grasrota. Blant egypterne spekuleres det $\mathrm{i}$ at partiet kan bli trukket inn på to ulike måter: For det første kan militære offiserer som føler seg forbigått av Gamal, søke å alliere seg med Muslimbrø drene for å hindre at han blir president. Offiserene vil kunne oppfordre muslimbrodre til å organisere demonstrasjoner og streiker over hele landet i protest mot et far-til-sønn presidentskifte. For det andre vil Gamal kunne velge å sette fri mange av de tusenvis av muslimbrødre som sitter fengslet i Egypt, mot at partiet gir ham sin støtte som president.

Imidlertid er det en farlig strategi for regimet, både på den ene og den andre måten, å alliere seg med den islamistiske opposisjonen. Strategien har tidligere med lite hell vært prøvd av både Nasser og Sadat. Begge invitere Muslimbrødrene inn i det politiske spillet for å få bredere støtte for sitt styre, men uten å tillate at partiet fikk reell innflytelse. Følgen av dette var skuffelse og forsterket misnøye med regimet blant islamistene.

\section{Politisk omlegging?}

Men i hvilken grad vil et lederskifte i Egypt bety en omlegging av landets politikk? På den ene siden er politikk i arabiske land kanskje mer avhengig av viljen og evnen til individuelle ledere enn i noen andre deler av verden. Dette taler for at et lederskifte potensielt kan få store konsekvenser for landets politikk. På den andre siden vil de

Egypt har i dag en befolkning som er politisk desillusjonert og ikke tror at et lederskifte vil spille noen rolle.

fleste statsledere i regionen være underlagt bestemte rammebetingelser som avhengigheten av støtte fra viktige samfunnssegmenter, og forholdet til andre regionale og internasjonale aktører. Dette taler for at det er grunn til å forvente en høy grad av kontinuitet i regimets politikk uavhengig av hvilken president som sitter ved makten.

Eberhard Kienle, ekspert på Egypts moderne politiske historie, hevder at det er vanlig å assosiere ulike epoker i landets historie etter I952 med Nasser, Sadat og Mubarak. Men til tross for dette mener han at lederne faktisk har hatt mindre å si for landets politikk enn andre interne og eksterne forhold. Kienle hevder blant annet at mange av bruddene i egyptisk politikk som ofte tillegges overgangen fra Nasser til Sadat i realiteten var endringsprosesser som hadde startet før selve presidentskiftet, og at det derfor var betydelig grad av kontinuitet fra den ene lederen til den neste. ${ }^{12}$

Hosni Mubarak, i motsetning til sine forgjengere, har vært en lite bemerkelsesverdig president. Han mangler Nassers karisma og Sadats energi, og går for å være fornuftig, konservativ og forutsigbar. Innenlandsk og regional stabilitet har vært hans hovedmål. Mubarak har unngått 
grove feil i sin 23-årige presidentperiode, men hans regime har frosset fast. En etterfølger vil måtte bruke lang tid for å tine opp systemet og eventuelt gjennomføre radikale omlegginger av Egypts innenriksog utenrikspolitikk.

Innenrikspolitikk: Hosni Mubaraks etterfølger vil videreføre militærregimet som ble opprettet i 1952. Gamal vil til tross for sin sivile bakgrunn også gjøre dette. Hans utdanning, omgangskrets og rolle som leder for sekretariatet med ansvar for å reformere NDP, har gjort at enkelte ser på han som en mulig agent for økonomisk- og kanskje også politisk liberalisering. Men selv om Gamal skulle ha en reformagenda, vil hans overlevelse som president vær avhengig av de som eventuelt bringer ham til makten. Generalene som kan bringe ham til makten - og holde ham der benytter kontroll over statsapparatet til personlig berikelse. Denne militærbyråkratiske eliten vil undergrave Gamals posisjon dersom han søker å gjennomføre reformer som truer deres kontroll over staten og dermed dens kilde til berikelse.

Utenrikspolitikk: Det er heller ingen grunn til å forvente en radikal omlegging av Egypts utenrikspolitikk etter Hosni Mubarak. Egypts distinkte trekk legger rammene for utenrikspolitikken uavhengig av hvem som er president. Det er derfor ingen grunn til å forvente et radikalt brudd med Mubaraks utenrikspolitikk. Daniel L. Byen lister tre trekk som vil legge rammene for en ny leders utenrikspolitikk: ${ }^{13}$

For det første eksisterer det en forventning i befolkningen om at Egypt skal spille en ledende rolle i den arabiske verden. Landet er det geografiske, demografiske, kulturelle og politiske tyngdepunktet $i$ den arabiske verden. En ny egyptisk president vil derfor videreføre et aktivt regionalt engasjement.

For det andre må en ny president forholde seg til Egypts militære styrker og svakheter. Landet er militært sterkt på papiret. Det besitter store mengder høyteknologiske våpen. Landet vil derfor trolig fortsette å yte militær støtte til arabiske stater, som det gjorde i I990 da egyptiske styrker ble utplassert i Saudi-Arabia som fryktet en irakisk invasjon. Men Egypt evner ikke å konfrontere Israel. Hærens kunnskap om bruk av avanserte våpensystemer er dårlig og den er ute av stand til å giennomføre koordinerte operasjoner. En militæ løsning er derfor ikke et alternativ dersom forholdet til Israel skulle forverres. For det tredje må en ny egyptisk president på den ene siden søke å tilfredsstille eliten som ønsker å opprettholde sine nære bånd til USA for å fortsatt kunne motta pengeog våpenstøtte, og på den andre siden imøtekomme grasrota i Egypt som er sterkt kritisk til landet. Presidenten vil trolig fortsette med forsiktig kritikk av USA, samtidig som han fortsetter å fungere som landets nyttige løpegutt i regionen.

\section{Konklusjon}

Under forutsetning av at president Mubarak og personer $i$ hans nærmeste krets faktisk har til hensikt å fremme Gamal Mubaraks presidentkandidatur vil deres muligheter for å lykkes avhenge av omstendighetene ved hans død. En snarlig bortgang for presidenten eller en vanskelig sikkerhetssituasjon, er faktorer som giør det sannsynlig at Mubaraks etterfølger vil komme fra de væpnede styrker eller sikkerhetsapparatet. Tantawi og Suleyman vil i en slik situasjon være åpenbare kandidater. Men dersom Hosni Mubarak fortsetter 
som Egypts president i ytterligere noen år og sikkerhetssituasjonen i landet er god nok til at reformprosessen i regimet fortsetter, kan Gamal opparbeide seg en posisjon som gjør ham i stand til å overta som president ved farens bortgang. Egypterne på gata vil trolig tenke at et fartil-sønn lederskifte ikke vil spille noen rolle og forholde seg passive.

Uansett er det er liten grunn til å forvente at et presidentskifte vil medføre en radikal omlegging av Egypts innenrikspolitikk. Alle de tre kandidatene kommer fra det etablerte maktapparatet, og har trolig verken evne eller vilje til å gjennomføre betydelige politiske reformer - i alle fall ikke på kort sikt. Rammene for utenrikspolitikken er langt på vei fastlagt av dagens alliansemønster og Egypts geopolitiske situasjon, og det er heller ingen grunn til å tro at noen av de nevnte kandidatene vil se seg tjent med en vesentlig kursendring i utenrikspolitikken.

\section{$\cdot f \cdot$}

I James Drummond: 'Cairo Confronts the Succession Taboo’, Economist Intelligence Unit, January 8, 2003

2 Mona el-Ghobashy: 'Antinomies of the Saad Eddin Ibrahim Case', Middle East Report Online, August I5, 2002 http://www.merip.org/mero/meroo8I502.html

3 Sentrale bidrag til denne debatten er Volker Perthes (ed): «Arab Elites. Negotiating the Politics of Change». Lynne Rienner Publications: Boulder/London:, 2004; Daniel L. Byen: 'The Implications of Leadership Change in the

A

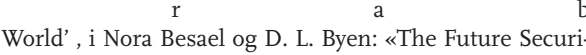

$\mathrm{t}$ Environment in the Middle East», RAND Project Air Force (Limited Distribution), 2004

4 Ibn Khaldun: The Muqaddimah: An Introduction to History. Princeton University Press, I989

5 Egypts konstitusjon på mangelsk: http://www.us.sis. gov.eg/egyptinf/politics/html/polfrm.htm

6 De samme navnene går igjen i spekulasjonene til forskere og journaliser opptatt med suksesjonsspørsmålet i Egypt. Se f. eks. Daniel Sobelman: ' Gamal Mubarak, President og Egypt?', Middle East Quarterly, Spring 200I http://www.meforum.org/article/27/; Brian Whitaker:

'Hereditary Republics in Arab States', The Guardian

don), August 2I, 200I

7 El Pais (Madrid), Mai 28, 2000

8 'Game over? Statements by Mubarak might have put an end to son's political future', Cairo Times, Vol. 7, Issue 4 2004

9 Ibid., s. 2

Io Gamal Abdelnasser: 'Egypt: Succession Politics', i V. Perthes, Volker (ed): Arab Elites.., 2004, s. I28-I33

II Eberhard Kienle:« A Grand Delusion: Democracy and Economic Reform in Egypt». I. B. Tauris Publishers: London/New York, 200I, S. I

I2 Ibid., S. I78-I83

I3 Daniel L. Byen op. cit.

I4 'Chiefs of State and Cabinet Members of Foreign Governments', Central Intelligence Agency, April 3, 200I http://www.cia.gov/cia/publications/chiefs/index.html 


\section{Statsoverhoder i et utvalg arabiske stater}

\begin{tabular}{|c|c|c|c|}
\hline Land & Statsoverhode & Fødselsår & Maktovertakelse \\
\hline Algerie & President Abdelaziz Bouteflika & I937 & I999 \\
\hline Bahrain & Emir Hamad bin Isa al-Khalifa & I949 & I999 \\
\hline Egypt & President Mubarak & I928 & I98I \\
\hline $\begin{array}{l}\text { Forente arabiske } \\
\text { emirater }\end{array}$ & $\begin{array}{l}\text { President Zayid bin Sultan al- } \\
\text { Nuhayyan }\end{array}$ & I9I8 & I97I \\
\hline Iran & President Khatami & I943 & I997 \\
\hline Jemen & President Ali Abdallah Salih & I942 & I978 \\
\hline Jordan & Kong Abdullah II & I962 & I999 \\
\hline Kuwait & $\begin{array}{l}\text { Emir Jabir al-Ahmad al-Jabir } \\
\text { al-Sabah }\end{array}$ & 1926 & I977 \\
\hline Libya & $\begin{array}{l}\text { Oberst Mu' ammar Abu Min- } \\
\text { yar al-Gadaffi }\end{array}$ & I942 & I969 \\
\hline Marokko & Kong Mohammed VI & I963 & I999 \\
\hline Oman & Sultan Qaboos bin Said al-Said & I940 & I970 \\
\hline $\begin{array}{l}\text { Palestinske } \\
\text { selvstyremyndigheter }\end{array}$ & President Yasser Arafat & I929 & I968 \\
\hline Qatar & $\begin{array}{l}\text { Emir Hamad bin Khalifa } \\
\text { al-Thani }\end{array}$ & I950 & I995 \\
\hline Saudi-Arabia & $\begin{array}{l}\text { Kong Fahd bin Abd al-Aziz } \\
\text { al-Saud }\end{array}$ & I923 & I982 \\
\hline Syria & President Bashar al-Assad & I966 & 2000 \\
\hline
\end{tabular}

